\title{
FIRST SPECIMEN OF THE NORTHERN SAW-WHET OWL FROM BAJA CALIFORNIA, MEXICO, WITH DATA ON ITS ABUNDANCE IN THE SIERRA SAN PEDRO MÁRTIR
}

\author{
TONATIUH GAONA-MELO, GONZALO DE LEÓN-GIRÓN, GORGONIO \\ RUIZ-CAMPOS, and IRAK RODRÍGUEZ-HERNÁNDEZ, Colección \\ Ornitológica, Facultad de Ciencias, Universidad Autónoma de Baja California, \\ Carretera Transpeninsular Ensenada-Tijuana no. 3917, Colonia Playitas, 22860, \\ Baja California, México; gruiz@uabc.edu.mx \\ PHILIP UNITT, San Diego Natural History Museum, P.O. Box 121390, San Diego, \\ California 92112-1390
}

During surveys (January 2018-November 2020) for the Northern Saw-whet Owl (Aegolius acadicus) in the Parque Nacional Sierra de San Pedro Mártir, Gaona-Melo collected one individual of this species at the site known as La Capilla $\left(31.011^{\circ} \mathrm{N}\right.$, $-115.534^{\circ} \mathrm{W}$, elevation 2336 meters above sea level) on 18 June 2020 (Figure 1). The specimen, a juvenile male measuring $190 \mathrm{~mm}$ in total length, $430 \mathrm{~mm}$ in wing span, $140 \mathrm{~mm}$ in wing chord, $76 \mathrm{~g}$ in weight (Figure 2), was taken by mist net at 21:36 during sampling for nocturnal raptors in a riparian stand of Quaking Aspen (Populus tremuloides) adjacent to mixed coniferous forest comprising Jeffrey Pine (Pinus jeffreyi), White Fir (Abies concolor), and Sugar Pine (Pinus lambertiana). The right testis measured $3.1 \times 1.8 \mathrm{~mm}$, the left $3.4 \times 1.4 \mathrm{~mm}$. This individual represents the first known specimen of this species in Baja California (Anthony 1893, Grinnell 1928, Wilbur 1987, Erickson et al. 2020). Furthermore, the age of the bird strongly suggests local nesting, being the first such evidence for Baja California. The

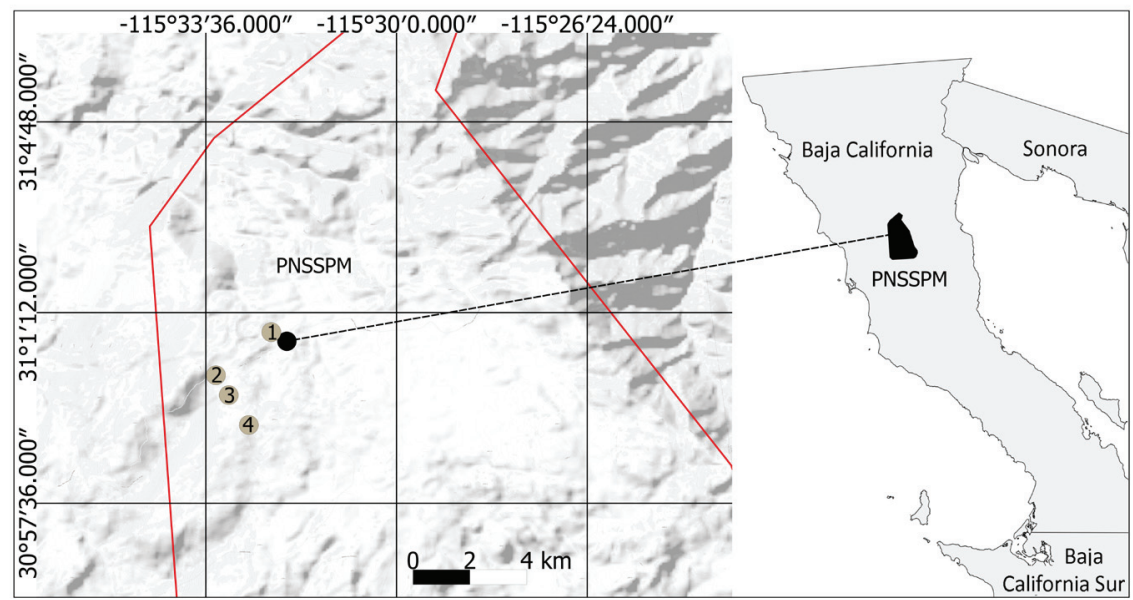

FIgURE 1. Collection and survey sites for the Northern Saw-whet Owl in the San Pedro Mártir National Park, Baja California, Mexico. (•) Collection site: La Capilla. Survey sites: (1) Arroyo Los Alamitos, (2) Corona de Arriba (camping area), (3) Charco de La Rana, and (4) Torre de Piedra. 


\section{NOTES}

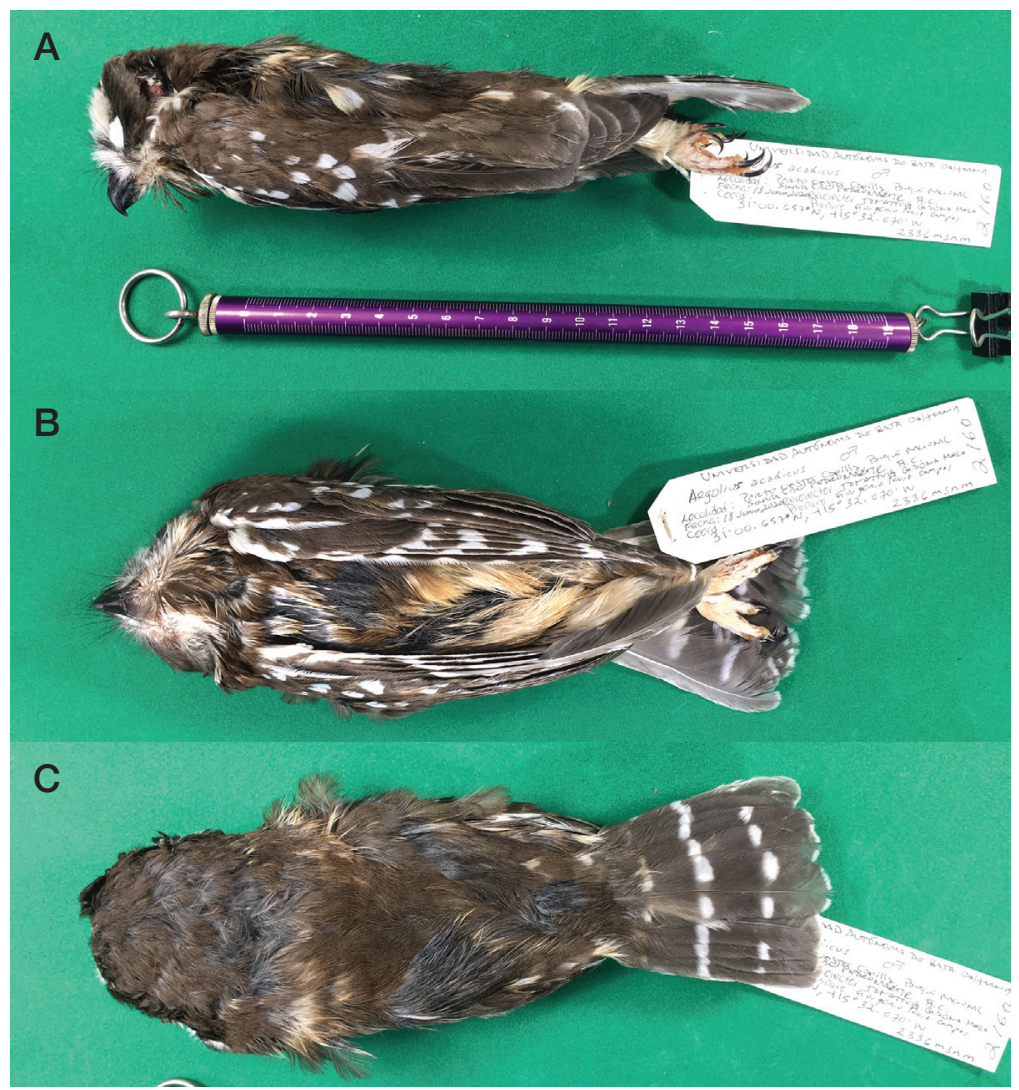

Figure 2. Lateral (A), ventral (B), and dorsal (C) views of the juvenile male specimen of the Northern Saw-whet Owl (Aegolius acadicus) collected at La Capilla, San Pedro Mártir National Park, Baja California, Mexico, 18 June 2020.

Photos by Gorgonio Ruiz-Campos

specimen is catalogued as number 2160 in the collection of birds of the Universidad Autónoma de Baja California.

The Northern Saw-whet Owl is widely distributed across much of North America from southern Alaska and southern Canada south to southern Mexico (American Ornithologists' Union 1998). In mainland Mexico, the Northern Saw-whet Owl occurs on both the Atlantic and Pacific slopes and in the interior, inhabiting the mountains from northeastern Sonora, Chihuahua, the Trans-Mexican Neovolcanic Belt, Puebla, and Hidalgo south to Oaxaca (Howell and Webb 1995, Lavariega et al. 2011), with isolated populations in southeastern Coahuila, southeastern Nuevo León, and northern San Luis Potosí (Holt et al. 1999). Its habitat includes humid to semi-humid pine, fir, and pine-oak forests (Howell and Webb 1995).

In the Baja California peninsula, Erickson et al. (1994) and Erickson and Wurster (1998) first reported this species from La Corona in the Parque Nacional Sierra de 
San Pedro Mártir, on the basis of calls and songs heard. Subsequent records (auditory or visual) have been reported from this same national park via www.ebird. org. During seasonal samplings (October 2017-August 2018) of nocturnal raptors, Rodríguez-Hernández (2019) recorded an average density of 1.7 individuals $/ \mathrm{km}^{2}$, in coniferous forest dominated by Jeffrey Pine. However, no specimens or even photographs have been taken for confirmation.

The population of Northern Saw-whet Owl nearest the Sierra San Pedro Mártir is located in the Laguna Mountains east of San Diego, over $200 \mathrm{~km}$ north (Unitt 2004). The Cedar Fire of 2003 may have extirpated Northern Saw-whet Owl from the Cuyamaca Mountains in central San Diego County, as since that year there has been only one report from those mountains to www.ebird.org, of a single individual in 2008. Farther north, the species is resident in small numbers on Volcan Mountain, Palomar Mountain, Hot Springs Mountain, and Santa Rosa Mountain (Unitt 2004).

Even though these southernmost populations are probably sedentary, a surprising number of wanderers have been found in atypical habitat in the deserts of southeastern Upper California. Patten et al. (2003) cited four records from the Colorado Desert, and two specimens were found at Picacho State Recreation Area along the Colorado River $33 \mathrm{~km}$ north of Yuma in the winter of 2000-2001 [San Diego Natural History Museum (SDNHM) 50579 and 50580]. There are three reports from Borrego Springs (N. Am. Birds 61:328, 2007; 62:303, 2008; 70:119, 2017) and at least two from the Coachella Valley (Palm Desert, N. Am. Birds 61:328, 2007, Los Angeles County Museum of Natural History 114591; Thousand Palms Oasis, N. Am. Birds 68:554,2015). Even though there are isolated resident populations on Santa Cruz and Santa Catalina islands, the only evidence of vagrancy toward the coast in San Diego County, is a specimen collected in the town of El Cajon just east of San Diego on 27 November 2015 (SDNHM 54658) and a bird photographed $7.5 \mathrm{~km}$ south of San Marcos in February 2016 (N. Am. Birds 70:232, 2018). Hamilton and Willick (1996) cited two occurrences at low elevations in Huntington Beach, Orange County. There are no records in Baja California away from the Sierra San Pedro Mártir.

In order to quantify the abundance of Northern Saw-whet Owl in the Parque Nacional Sierra de San Pedro Mártir, we carried out a total of 67 nocturnal surveys at four sites from January 2018 to November 2020, encompassing all the seasons of the year (Figure 1, Table 1). The survey areas were defined by transects located in forest suitable for this species as identified from observations in 2017 (RodríguezHernández 2019). The survey points were spaced $1 \mathrm{~km}$ apart (Groves et al. 1997). At each survey point, we started with 1 minute of silence to assess the presence or absence of other owl species in the site (Valencia et al. 2012). Northern Saw-whet Owl calls were broadcast intermittently (Fuller and Mosher 1981), in the pattern of 1 minute of broadcast, 4 minutes of silence, 1 minute of broadcast, 4 minutes of silence, 1 minute of broadcast, and finally 4 minutes of silence, all this giving a total sampling effort of 15 minutes per point (Aguilar et al. 2001). Also, the sampling at each survey point was stopped as soon as a different owl species, either the Great Horned Owl (Bubo virginianus) or Long-eared Owl (Asio otus) was detected. The number of individuals detected per hour at each site of sampling is shown in Table 1 , with a total average for all sites and seasons pooled of 2.6 individuals. Locally (all seasons pooled), the highest frequency of individuals detected per hour was at Charco de la Rana (3.3) followed by Corona de Arriba. Seasonally (all sites pooled), the higher frequency of individuals detected per hour was in winter and fall with 2.7 and 2.9 , respectively (Table 1 ).

We thank personnel from the Parque Nacional Sierra de San Pedro Mártir, especially Francisco Arce, Juan Pablo Medina, Daniel Orona, Juan Bencomo, Alfredo Madriles, Diego Toscano, Gustavo Bencomo, and Aldo Guevara for help in the field sampling and logistic support for this study. Richard A. Erickson made useful comments and suggestions that improved the content of the manuscript. 


\section{NOTES}

TABLE 1 Results of Surveys for Aegolius acadicus in San Pedro Mártir National Park, January 2018-November 2020

\begin{tabular}{lcccccc}
\hline Locality and data of surveys & Dates of sampling & Winter & Spring & Summer & Fall & Total \\
\hline 1. Arroyo de Los Alamillos & 23 Jan 2018- & & & & & \\
& 30 Sep 2020 & 5 & 8 & 15 & 2 & 30 \\
Number of surveys & & 5 & 9 & 27 & 3 & 44 \\
Number of records & & 2.9 & 5.4 & 10.3 & 0.5 & 19.1 \\
Sampling effort (hours) & & 1.7 & 1.7 & 2.6 & 6.0 & 2.3 \\
Individuals detected per hour & 27 Jan 2018- & & & & & \\
2. Corona de Arriba & 22 Nov 2020 & 6 & 2 & 3 & 19 & 30 \\
Number of surveys & & 9 & 2 & 3 & 33 & 47 \\
Number of records & 2.5 & 0.9 & 0.7 & 11.7 & 15.8 \\
Sampling effort (hours) & & 3.6 & 2.2 & 4.3 & 2.8 & 3.0 \\
Individuals detected per hour & 27 Oct 2018- & & & & & \\
3. Charco de La Rana & 9 Nov 2019 & 0 & 1 & 0 & 2 & 3 \\
Number of surveys & & 0 & 2 & 0 & 2 & 4 \\
Number of records & & 0 & 0.5 & 0 & 0.7 & 1.2 \\
Sampling effort (hours) & & 0 & 4 & 0 & 3 & 3.3 \\
Individuals detected per hour & 5 Jul 2019- & & & & & \\
4. Torre de Piedra & 9 Feb 2020 & 1 & 1 & 2 & 0 & 4 \\
Number of surveys & & 1 & 1 & 2 & 0 & 4 \\
Number of records & & 0.2 & 0.7 & 1.6 & 0 & 2.5 \\
Sampling effort (hours) & & 5 & 1.4 & 1.3 & & 1.6 \\
Individuals detected per hour & 23 Jan 2018- & & & & & \\
All sites pooled & 22 Nov 2020 & 12 & 12 & 20 & 23 & 67 \\
Number of surveys & & 15 & 14 & 32 & 38 & 99 \\
Number of records & & 7.6 & 1.9 & 2.5 & 2.9 & 2.6 \\
\hline Sampling effort (hours) & & & & & & \\
Individuals detected per hour & & & & & & \\
\hline
\end{tabular}

\section{LITERATURE CITED}

Aguilar, A., Paniagua, D., Illana, A., and Martínez, F. 2001. Estudio de la comunidad de rapaces nocturnas en el territorio histórico de Álava. Report to the Gobierno Vasco by Grupo Alavés para la Defensa y Estudio de la Naturaleza, Vitoria-Gasteiz, Spain; http://www.faunadealava.org/adjuntos/faunadealavaDocumentos/12_archivo.pdf.

American Ornithologists' Union. 1998. Check-list of North American Birds, 7th ed. Am. Ornithol. Union, Washington, DC.

Anthony, A. W. 1893. Birds of San Pedro Mártir, Lower California. Zoe 4:228-247.

Erickson, R. A., and Wurster, T. E. 1998. Confirmation of nesting in Mexico for four bird species from the Sierra San Pedro Mártir, Baja California. Wilson Bull. 110:118-120.

Erickson, R. A., Barron, A. D., and Wurster, T. E. 1994. Northern Saw-whet Owl in the Sierra San Pedro Mártir: First Baja California record. W. Birds 25:66-68.

Erickson, R. A., Marrón, G., Zamora-Hernández, E. D., and Billings, M. J. 2020. Notable bird observations for Baja California and Baja California Sur, August 2016 through December 2019, with an updated checklist for the states. N. Am. Birds; https://www.aba.org/baja-california-fall-2016-fall-2019/.

Fuller, M. R., and Mosher, J. A. 1981. Methods of detecting and counting raptors: 


\section{NOTES}

A review, in Estimating the Numbers of Terrestrial Birds (C. J. Ralph and J. M. Scott, eds.), pp. 235-246. Studies in Avian Biol. 6.

Grinnell, J. 1928. A distribution summation of the ornithology of Lower California. Univ. Calif. Publ. Zool. 32:1-300.

Groves, C., Frederick, T., Frederick, G., Atkinson, E., Atkinson, M., Shepherd, J., and Servheen, G. 1997. Density, distribution and habitat of Flammulated Owls in Idaho. Great Basin Nat. 57:116-123.

Hamilton, R. A., and Willick, D. R. 1996. The Birds of Orange County, California: Status and Distribution. Sea and Sage Press, Irvine.

Holt, D. W., Berkley, R., Deppe, C., Enríquez, P. L, Olsen, P. D., Petersen, J. L., Rangel, J. L., Segars, K. P., and Wood, K. L. 1999. Strigidae, in Handbook of the Birds of the World (J. del Hoyo, A. Elliott, and J. Sargatal, eds.), vol. 5, pp. 153-242. Lynx Edicions, Barcelona.

Howell, S. N. G., and S. Webb. 1995. A Guide to the Birds of Mexico and Northern Central America. Oxford Univ. Press, Oxford, England.

Lavariega, M. C., Martín-Regalado, N., Rodríguez-Pérez, C., and Gómez-Ugalde, R. M. 2011. Registro del tecolote afilador (Aegolius acadicus) en las montañas y valles del occidente de Oaxaca, México. Huitzil 12:48-52.

Patten, M. A., McCaskie, G., and Unitt, P. 2003. Birds of the Salton Sea. Univ. of Calif. Press, Berkeley; doi.org/10.1525/9780520929449.

Rodríguez-Hernández, I. 2019. Composición espacio-temporal de rapaces nocturnas en el Parque Nacional Sierra de San Pedro Mártir, Baja California, México. B.Sc. thesis, Facultad de Ciencias, Univ. Autónoma de Baja California, Ensenada, México.

Unitt, P. 2004. San Diego County Bird Atlas. Proc. San Diego Soc. Nat. Hist. 39.

Valencia, J., Ortiz, R., and Enríquez, P. 2012. Riqueza y distribución espacial de rapaces nocturnas en Hidalgo, México. Huitzil 13:116-129.

Wilbur, S. R. 1987. Birds of Baja California. Univ. of Calif. Press, Berkeley.

Accepted 23 February 2021 